\title{
ВИКОРИСТАННЯ СУЧАСНИХ МЕТОДІВ ЗАКРІПЛЕННЯ ВИВЧЕНОГО МАТЕРІАЛУ ДЛЯ РОЗВИТКУ У СТУДЕНТІВ КОМУНІКАТИВНИХ КОМПЕТЕНЦІЙ ТА НАВИЧОК КОНСУЛЬТУВАННЯ
}

\author{
Новикова Л. Г., \\ старший викладач, Кафедра фармацевтичного менеджменту, клінічної фармащії, технологї \\ ліків, Україна, Київ, ПВНЗ «Київський медичний університет» \\ ORCID ID: https://orcid.org/0000-0001-5103-1016,
}

Білан О. А., стариий викладач, Кафедра фармачевтичного менеджменту, клінічної фармації, технології ліків, Україна, Київ, ПВНЗ «Київський медичний університет»

ORCID ID: https://orcid.org/0000-0002-2720-6864,

Kyxap O. O., к.фарм.н., дочент, Кафедра фармацевтичного менеджменту, клінічної фармації, технології ліків, Україна, Київ, ПВНЗ «Київський медичний університет»

ORCID ID: https://orcid.org/0000-0002-2785-4001

DOI: https://doi.org/10.31435/rsglobal_ws/30062020/7117

\section{ARTICLE INFO}

Received: 14 April 2020

Accepted: 19 June 2020

Published: 30 June 2020

\section{KEYWORDS}

interactive methods of teaching students, consolidating the learned material, continuing pharmacy professional development, patient counselling skills, communication skills.

\begin{abstract}
The article considers the modern approach to the consolidation of new knowledge and the formation of consulting skills of students-pharmacists, particularly the use of interactive methods and modern gadgets for homework completion to ensure the development of communicative competencies.
\end{abstract}

Citation: Novykova L. G., Bilan O. A., Kukhar O. O. (2020) Usage of Modern Learning Material Embadding Methods for Development of the Communication Competencies and Consulting Skills. World Science. 6(58), Vol.3. doi: 10.31435/rsglobal_ws/30062020/7117

Copyright: (C) 2020 Novykova L. G., Bilan O. A., Kukhar O. O. This is an open-access article distributed under the terms of the Creative Commons Attribution License (CC BY). The use, distribution or reproduction in other forums is permitted, provided the original author(s) or licensor are credited and that the original publication in this journal is cited, in accordance with accepted academic practice. No use, distribution or reproduction is permitted which does not comply with these terms.

Вступ. В Україні, як і в інших країнах, постійно підвищується роль відповідального самодогляду та самолікування (responsible self-care and self-medication) пацієнтів. В документах Всесвітньої організації охорони здоров'я (ВООЗ) і Програми дій з основних лікарських препаратів, затвердженої Європейським регіональним бюро ВООЗ, також підкреслюється «фокус на пацієнта», спрямування медицини на його потреби. Зміни у суспільстві вимагають докорінних перемін у системі охорони здоров'я, в тому числі, формування у медиків нових практичних навичок у галузі консультування. Особливо актуальне це для клінічних провізорів $\mathrm{i}$ фармацевтів, котрі працюють в аптечних мережах та в закладах охорони здоров’я.

Нові вимоги відображені у Стандартах фармацевтичної опіки (Pharmaceutical Care) [1], які вимагають від фармацевтичного працівника вміння працювати 3 пацієнтами різних вікових груп (новонароджені, діти, неповнолітні, похилого віку, а також жінки в період вагітності та лактації). 
Модель ВОО3 Seven-star pharmacist concept [4] — «Сім нових ролей фармацевта» також наголошує на необхідності розширення функціональних обов'язків фармацевтів і провізорів та опануванні ними нових ролей: «той, хто доглядає»; «той, хто приймає рішення»; «комунікатор»; «керівник»; «той, хто навчається впродовж усього життя»; «педагог»; «лідер» (див. рис. 1).

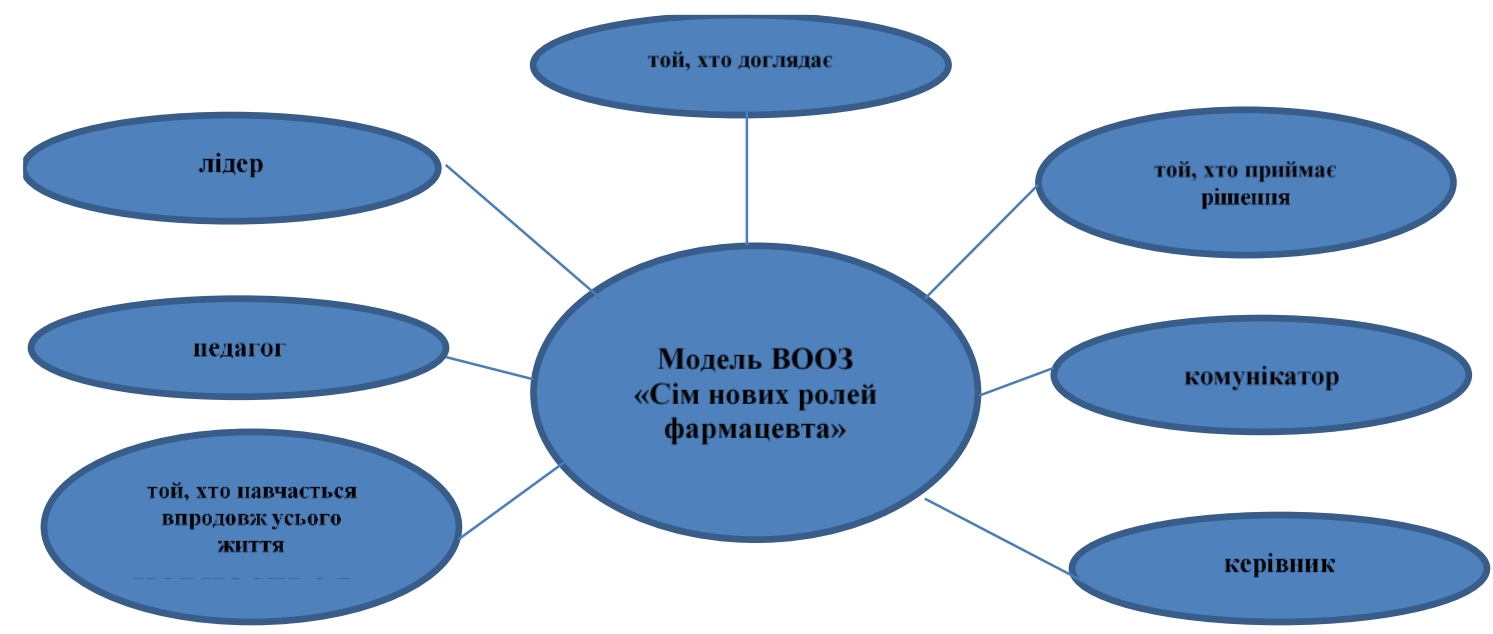

Рис. 1. Модель ВООЗ «Сім нових ролей фармацевта»

Тобто сьогодні фармацевтична допомога (pharmaceutical care) — це не лише виготовлення та продаж ліків, а й «оптимізація результатів лікування пацієнтів, прийняття відповідальності за ефективне, раціональне та безпечне використання лікарських засобів» [5]. Отже, формується нова дисципліна «Соціальна взаємодія: провізор - лікар — пацієнт», що зосереджена на комунікативних аспектах професії. Як комунікатор провізор є посередником між лікарем і пацієнтом, тому потребує:

1) високого рівня розвитку мовних навичок (усної та невербальної, аудіювання та письма);

2) психологічної стійкості та стресостійкості, впевненості у собі, вміння керувати своїми емоціями;

3) вміння взаємодіяти з іншими медичними працівниками та громадськістю.

Саме тому фахівці Міжнародної асоціації комунікації в галузі охорони здоров'я (International Association for Communication in Healthcare, EACH) постійно наголошують, що «ефективна комунікація необхідна для високоякісної клінічної практики, тому що вона забезпечує: індивідуальний догляд, поважаючий самостійність пацієнта; більшу безпеку і ефективність охорони здоров'я; поліпшення результатів лікування; більш високий рівень задоволеності пацієнтів і більш економічне медичне обслуговування» [3].

Мета дослідження. Апробувати сучасний підхід до закріплення нових знань та формування навичок консультування у студентів-провізорів (пілотний проект). Довести ефективність використання інтерактивних методів навчання та сучасних гаджетів під час виконання домашніх завдань та їх важливість для розвитку комунікативних компетенцій провізорів.

Методи дослідження. Експеримент, спостереження, аналіз профільної літератури (першоджерел); контент-аналіз текстів.

Результати дослідження. Щоб підготувати майбутніх фахівців до нових обов'язків, сформувати у них вміння і навички з консультування пацієнтів (Patient Counselling Skills) необхідні більш практико-орієнтовані навчальні програми, використання нових ефективних методів навчання, тому у вітчизняних медичних та фармацевтичних вузах вже широко застосовуються мультимедійний супровід та обговорення кейсів. Але для більш результативного формування практичних навичок необхідно ще й емоційне залучення студентів у виконання учбових завдань. Наш досвід засвідчує, що цьому сприяє використання сучасних гаджетів.

Ще Конфуцій казав: «Я почув і забув. Я побачив і запам'ятав. Я зробив і зрозумів». Ця мудрість підтверджується сучасними розробками методистів. Наприклад, широко відома освітянам модель «конус досвіду Е. Дейла» (Dale's cone of experience) включає в себе декілька теорій, пов'язаних 3 навчальним процесом, а розроблена на основі «конуса Дейла» «піраміда навчання» (див. рис. 2), відображає вплив методів навчання на ступінь засвоєння матеріалу. 


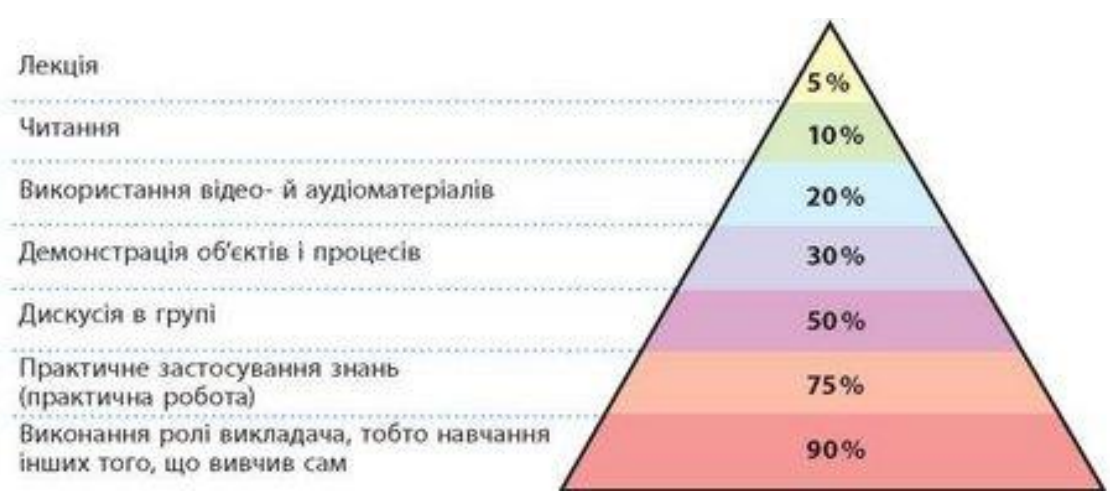

Рис. 2. «Піраміда навчання» (відсоток засвоєння матеріалу)

Очевидно, що найбільш ефективними є методи, що базуються на взаємодії «викладачстудент» та «студент-студент». Інтерактивний підхід дозволяе навчити самостійно шукати та аналізувати інформацію, приймати рішення та працювати в команді. Але головним є те, що у студентів значно підвищується мотивація до навчання, покращується запам'ятовування матеріалу та швидше формуються потрібні навички.

Опанування протоколів фармацевтичної опіки (ФО) та алгоритмів співбесід з пацієнтами досить складна задача, бо під час бесіди потрібно дотримуватися певної послідовності запитань (в залежності від конкретної хвороби), та ще й дерево бесіди має розгалужуватися в залежності від симптомів. До того ж пацієнт може ставити додаткові запитання, додатково скаржитись на щось, або поводитися неадекватно. 3 особливими утрудненнями стикаються студенти, які мають невеликий досвід спілкування з незнайомими людьми, особливо 3 літніми, 3 вадами розвитку (порушеннями зору, слуху), агресивно налаштованими і т. ін.

Щоб допомогти студентам сформувати необхідні комунікативні навички та вміння консультувати ми використовуємо різноманітні активні методи, такі як групова робота, робота 3 партнером, розігрування кейсів і т. п. [2]. Але досить насичена навчальна програма не дозволяє виділити у розкладі занять значну кількість годин на відпрацювання практичних навичок. Тому ми вирішили використовувати для цього інтерактивні домашні завдання. На нашу думку, сильною стороною молоді $є$ захоплення новітніми технологіями, вільне володіння сучасними гаджетами, тому ми запропонували студентам знімати виконання ними домашніх завдань - робити невеличкі відео-роліки за допомогою смартфону. Виконувати зйомку можна самостійно або разом з одногрупниками. Наприклад:

1. Студенти IV курсу навчання під час вивчення дисципліни «Соціальна взаємодія: провізор - лікар - пацієнт» отримують завдання: «провести верифікацію лікарського препарату». Кожен із студентів має:

- впізнати препарат (хімічна і торгова назва, фармакологічна група);

- вказати показання до застосування;

- описати взаємодію з іншими ліками та можливі ускладнення.

Студент бере упаковку й розказує на камеру все, що знає про цей конкретний препарат (див. скріншот на рис. 3).

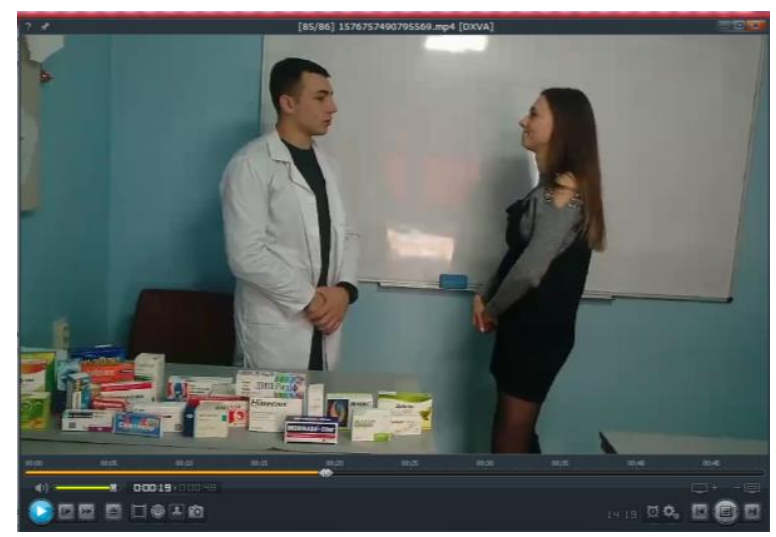

Рис. 3. Кадр з відеоролику (IV курс, украӥномовні студенти) 
2. Ha IV i V курсах в рамках дисципліни «Клінічна фармація та фармацевтична опіка» студенти відпрацьовують алгоритми спілкування з пацієнтами різного віку, 3 різними захворюваннями та виконують більш складні ситуаційні вправи (див. скріншот на рис. 4).

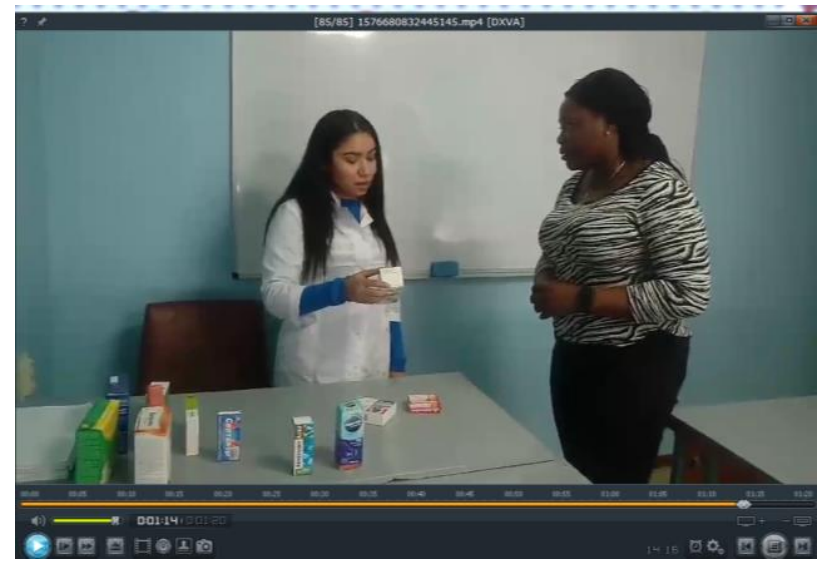

Рис. 4. Кадр з відеоролику (IV курс, англомовні студенти)

Виконане завдання (відео-ролік) кожен студент надсилає викладачу через електронну пошту. Середня тривалість відеоматеріалу - 2-5 хвилин, в залежності від складності завдання.

На початку наступного заняття група студентів переглядає всі ролики, що, по суті, $\epsilon$ додатковим повторенням та закріпленням вивченого матеріалу. До того ж перегляд:

1) прискорює перевірку домашніх завдань;

2) концентрує увагу всієї групи на навчальній темі;

3) підвищує мотивацію студентів до навчання.

Під час перевірки домашніх завдань ми не акцентуємо уваги на якості зйомки, технічних деталях або акторських здібностях студентів, а пропонуємо всій групі оцінити правильність та повноту відповіді. Викладач, зі свого боку, має можливість:

- прокоментувати поведінку студентів під час виконання вправи;

- привернути увагу до невербальних ознак комунікації (жести, міміка, мова тіла, тон голосу);

- пояснити важливість використання запитів різного виду (відкриті, закриті, нейтральні).

На власному досвіді студенти починають краще розуміти теоретичні знання, такі, як «вміння підтримувати зоровий контакт» та «віддзеркалювати» поведінку співрозмовника, а головне, переконуються в їх важливості для успішної взаємодії з іншими людьми.

Висновки та перспективи подальших досліджень. Використання відео зйомки під час виконання домашніх завдань сприяє формуванню/відпрацюванню студентами «м'яких навичок» (soft skills) — вмінню ефективно спілкуватися та консультувати пацієнта, що вкрай необхідні провізорам на робочому місці. Самостійна робота допомагає їм зрозуміти, що таке фармацевтична допомога, а головне, дуже мотивує до навчання, виявлення своїх творчих здібностей.

Всі завдання можна виконувати самостійно, але найчастіше студентам подобається робити це разом з одногрупниками. Ми заохочуємо колективну працю, тому що в такому разі паралельно відпрацьовуються додаткові вміння (взаємодія з колегами в малій групі, вміння планувати свою діяльність), а також формується психологічна стійкість - вміння контролювати свої емоції та почуватися впевнено під час розмови з пацієнтом.

В подальшому ми плануємо:

1) проаналізувати вплив виконання домашніх вправ на підвищення якості засвоєння теоретичного матеріалу і формування навичок консультування;

2) відібрати кращі відео-роліки для використання в учбовому процесі;

3) розширити тематику домашніх завдань для відеозйомок за рахунок опрацювання типових та складних комунікативних ситуацій (вивчення потреб пацієнта, вирішення та попередження конфлікту і т. п.).

Виконання комунікативних відеовправ допоможе майбутнім провізорам краще підготуватися до реалій професійного життя, а саме: навчитися ефективно комунікувати з різними людьми (поводитися ассертивно, активно слухати), захищати себе на робочому місці від вербальної агресії, впевнено почуватися у нестандартних ситуаціях, правильно реагувати на скарги пацієнтів і 
т. ін. Важливість даного методу в процесі навчання підтверджують численні дані наукових досліджень, в яких підкреслюється, що використання відеоматеріалів надає можливість:

1) сегментувати матеріал та надавати чіткі пункти для зупинок (вони потрібні для роздумів або огляду);

2) проводити інтеграцію з іншими матеріалами курсу, такими як текст або групове обговорення;

3) приводити докладні приклади взаємодій для аналізу та демонструвати конкретні аспекти міжособистісного спілкування через бібліотеку хороших і поганих прикладів.

\section{ЛIТЕРАТУРА}

1. Vykorystannia likarskykh zasobiv - farmatsevtychna opika. Navchalno-metodychnyi posibnyk dlia studentiv 5 kursu farmatsevtychnoho fakultetu spetsialnosti «Farmatsiia»/ O.V. Kraidashenko, O.O. Svyntozelskyi // ZDMU - Zaporizhzhia. 2017 - 282 s.

2. Communication Skills in Pharmacy Practice: A Practical Guide for Students and Practitioners (5th Edition) By William N Tindall, Robert S Beardsley and Carole L Kimberlin 2011, 242 pages, Lippincott Williams \& Wilkins. Ethiopian Journal of Health Sciences, 22(1), 67-69.

3. International Association for Communication in Healthcare (EACH). (2019, December 11). Retrieved from: https://www.each.eu/about-us/

4. The Role of the Pharmacist in the Health-Care System - Preparing the Future Pharmacist: Curricular Development / Report of a Third WHO Consultative Group on the Role of the Pharmacist. 1997 Vancouver, Canada. 